\title{
Going viral: a COVID-19 story
}

\author{
Udaya K Ranawaka ${ }^{1}$ \\ Journal of the Ceylon College of Physicians, 2020, 51, 4-7
}

Key words: Covid-19, SARS-CoV-2, ethics, health care professionals, pandemic, impact

\author{
"Swift as the wind, quiet as the forest, conquer \\ like the fire, ..." \\ - Sun Tzu, The Art of War
}

A tiny little virus has taken the world by storm. In a span of a few months, it has stopped the world in its tracks, turned it on its head, and brought it down to its knees. And it has been a great leveller, paying scant regard to geographical boundaries, ethnic and religious divisions or the political might of superpowers. Every nation was at its mercy; it simply was a matter of time when the virus would knock on their door. As it marched relentlessly from country to country and from continent to continent, it has left in its wake societies in chaos, economies in shambles, governments in despair and health care systems gasping for breath. The world, as we knew it, has changed for ever. In the blink of an eye, in terms of galactic time.

The first signs of the outbreak were noted in the city of Wuhan in China when four unusual cases of pneumonia were reported on $27^{\text {th }}$ December 2019, followed soon after by many more. As the outbreak unfolded, the Chinese health authorities commenced what turned out to be an exemplary public health response. The source of infection was traced to the Huanan wet seafood market, which was promptly closed on $1^{\text {st }}$ January 2020; a novel coronavirus responsible for the outbreak was identified on $7^{\text {th }}$ January; the viral genome was internationally shared on $12^{\text {th }}$ January; and first PCR test kits for viral detection were made available on $13^{\text {th }}$ January ${ }^{1}$. The virus was initially named the 2019 novel coronavirus (2019-nCoV) by the WHO on $11^{\text {th }}$ January 2020 . The nomenclature was later changed to severe acute respiratory syndrome coronavirus-2 (SARS-CoV-2), and the disease was officially labelled COVID-19 (coronavirus disease 2019) on $11^{\text {th }}$ February $2020^{2,3,4}$. The WHO was first notified of the outbreak by the Chinese health authorities on $31^{\text {st }}$ December 2019; as the virus spread across continents, the WHO designated the outbreak a Public Health Emergency of International Concern on $30^{\text {th }}$ January 2020 , and declared it a pandemic on $11^{\text {th }}$ March $2020^{1}$.

Pandemics have been man's constant companion throughout human history; as man moved from continent to continent, infections followed with staggering losses of human lives. The 'Black Death' in the $14^{\text {th }}$ century (due to bubonic plague) is estimated to have killed 200 million people, the smallpox pandemic in the $17^{\text {th }}$ century killed 56 million, and the 'Spanish flu' in the last century killed 50-60 million people ${ }^{5}$. At the time of writing, in mid-May 2020, COVID-19 has spread to over 200 countries in all the continents, infected almost five million people and left over 300,000 dead ${ }^{6}$. It is reported to have claimed more American lives in one month than the death toll in the Vietnam War over 8 years $^{7}$.

\section{"Fever itself is Nature's instrument." \\ - Thomas Sydenham}

Over the last few months, COVID-19 has changed the world. Life on the planet became unrecognisable, as quarantines, lockdowns and social distancing became the order of the day. Schools and universities, shopping malls and street markets, restaurants and

\footnotetext{
${ }^{1}$ Professor in Neurology, Faculty of Medicine, University of Kelaniya, Sri Lanka.

Correspondence: E-mail: udayaran@yahoo.com
}

(iD) http://orcid.org/0000-0002-4050-062X

Received 18 May 2020, accepted 22 May 2020.

This is an open-access article distributed under the terms of the Creative Commons Attribution License, which permits unrestricted use, distribution, and reproduction in any medium, provided the original author and source are credited. 
wayside cafes, salons and barbershops, and beaches and parks were all closed, and cities were turned into ghost cities overnight. Trade and economic activities were disrupted worldwide, millions of jobs were lost, airlines declared bankruptcy and businesses simply shut down operations. Countries faced bleak economic forecasts, as productivity plummeted with the lockdowns and medical expenditure soared to meet the requirements of COVID-19 care. The Asian Development Bank estimates the global economic impact of the pandemic to be a staggering 8.8 trillion US dollars ${ }^{8}$, and the International Monetary Fund predicts the global economy to shrink by more than $3 \%$ in 2020 , the most dramatic economic slowdown since the Great Depression of the $1930 s^{9}$.

Arguably, the biggest impact of the pandemic has been on the health care systems of the world, caught wrong-footed and forced to play catch-up. As the number of COVID-19 cases and deaths skyrocketed, hospitals were in a losing battle to provide appropriate care. Shortages were everywhere, in diagnostic test kits, personal protective equipment (PPEs) for health care workers, ICU beds, ventilators and manpower. Even the most developed health care systems in the world had a health care crisis on their hands. In many countries, patients were simply advised to stay home, and seek hospital care only if severely ill. The human touch in patient care was lost as glass partitions separated patients from health care providers. Ethics of patient care fell by the wayside as demand simply outstripped available resources; ICU beds and ventilators were rationed and 'do-not-resuscitate' decisions were made based on the age of the patients, their co-morbidity and disability status ${ }^{10-14}$. The dead were denied their final farewells and traditional death rituals. There were no easy solutions to the many ethical dilemmas posed by the pandemic ${ }^{15,16}$.

Meanwhile, health care workers were being thrust into clinical roles they were unaccustomed to and not trained for. Thousands were infected and died in the line of duty due to many intertwining factors, such as lack of PPEs, exhaustion due to extraordinary workloads and suicide from mental stress and depression $17,18,19$. A United Nations Policy Brief observed that $47 \%$ of Canadian healthcare workers reported a need for psychological support and $50 \%$ of Chinese healthcare workers reported high rates of depression ${ }^{20}$. In a qualitative study conducted in the Hubei province, China, health care workers in the first epicentre of the pandemic have highlighted the many challenges in providing dedicated care while facing overwhelming workloads, physical discomfort of working long hours in PPEs, fears regarding personal and family well-being and the emotional distress in looking after countless dying patients ${ }^{21}$. Their insights are a reflection of the professional commitment displayed by millions of health care workers across the world in trying circumstances, the real human heroes in this pandemic. A call has been made to prevent a 'parallel pandemic' of the clinical workforce and protect their well-being and safety ${ }^{17}$.

As hospitals across the world were overwhelmed with COVID-19 cases and all available resources were diverted to fight the pandemic, care of the non-COVID19 patients suffered, a hidden health care crisis that is still waiting to be properly documented. In a worrying turn of events, patients seemed to lose faith in the very hospital structure that was supposed to look after them in times of need. Admissions of patients to emergency departments with life-threatening emergencies such as acute coronary syndromes and strokes fell by $40-50 \%$, as patients viewed hospitals as potential 'reservoirs of infection' ${ }^{22,23,24}$. A study from USA reported that the number of cardiac arrests in the field increased by $45 \%$ as patients waited too long to seek cardiology admissions, and patients with stroke arrived several days after onset, too late for acute treatments such as thrombolysis and endovascular treatment ${ }^{22}$. A substantial increase in mortality ranging from 39 to $75 \%$, compared with expected mortality, was seen at population level in an international comparative study, and $20-47 \%$ of these deaths were not attributable to COVID-1925.

\section{"War must be, while we defend our lives against a destroyer who would devour all."}

- J.R.R. Tolkien, 'The Lord of the Rings: Two Towers'

And the medical world fought back, hobbling back to its feet and trying to defend itself against an invisible foe. In ways unprecedented. Across the world, hospitals developed new triage systems, mapped out care pathways and fashioned intensive care units out of nothing. Professionals in many unrelated disciplines, such as gynaecologists, orthopaedic surgeons, otolaryngologists and ophthalmologists were drafted into COVID-19 care. Manufacturing companies ramped up the production of PCR and antibody test kits, PPEs and respirator masks, sanitizers and disinfectants, and other medical supplies required to meet the surge in demand. The use of virtual health technology expanded dramatically as telemedicine was adopted to provide outpatient care in patients' homes, to 'forward triage' suspected COVID-19 patients before they came to 
hospital, and for remote electronic monitoring of ICU patients in multiple hospitals $\mathrm{s}^{26,27}$. The health care crisis inspired a wide array of innovations; robot vehicles capable of transporting food and medicines to patients, drones guided by artificial intelligence to disinfect closed spaces, use of 3D printing to produce mechanical ventilators, wireless devices for remote monitoring of patient parameters, digital tracking devices to map infection spread, and hands-free door handles and wrist mounted hand sanitisers, to name a few ${ }^{28,29}$.

Scientists raced against time to test new treatments, develop vaccines and to find new ways to fight the virus. Old drugs such as chloroquine and hydroxychloroquine were repurposed, and were being tried and tested hand in hand with newer 'magic bullets' such as remdesivir and tocilizumab in a bid to find a cure. Academic boundaries were broken down and ideological differences cast aside as knowledge on the virus and the disease was freely shared across the world. New insights were disseminated globally within hours by the social media. In an era when scholarly articles have become pieces of merchandise, international journals made all publications on COVID19 available free of charge. Research into COVID-19 flourished; a PubMed search using the search term "covid 19" on the $14^{\text {th }}$ of May, barely six months after the first reported case in Wuhan, yielded an astounding 12,103 publications ${ }^{30}$. A search of the WHO's International Clinical Trial Registry Platform Search Portal on the same day showed that 2464 clinical trials into COVID-19 were registered in various international clinical trial registries ${ }^{31}$. Several vaccine trials commenced recruitment, offering hope of prevention at last ${ }^{32}$.

\section{"And the world will live as one."}

- John Lennon, 'Imagine'

Battered and bruised, but not yet beaten, people across the world joined together to savour small victories. Several countries, such as China, Taiwan, South Korea and Hong Kong appear to have been able to ride out the initial storm, offering a glimmer of hope to the rest of the world embroiled in the war with the virus. Lessons learnt from them can be used by other countries to plan strategies and countermeasures, even in this late hour. It is important, however, to be aware that initial appearances of control can be deceptive and may be followed by the so called 'second wave' of infection leading to more infections and deaths.
Although leaving a trail of death and despair, the COVID-19 infection may have brought a divided world together. Countries have shed their ideological and political differences, shared knowledge and resources, and worked together in a fight for survival. Hopefully, they will build on this platform of cooperation to improve global health and save mankind from another 'Black Death'. Universal implementation of 'One Health' approaches that acknowledge the close interplay between the health of the people, health of the animals and health of the planet will go a long way in preventing future pandemics ${ }^{33}$.

We live in hope. Until the next pandemic comes calling.

\section{References}

1. Wu Z, McGoogan JM. Characteristics of and Important Lessons from the Coronavirus Disease 2019 (COVID-19) Outbreak in China. Summary of a Report of 72314 Cases from the Chinese Center for Disease Control and Prevention. JAMA. 2020; 323(13): 1239-42. doi:10.1001/jama.2020.2648

2. World Health Organization. 2020. Novel Coronavirus (2019nCoV): situation report, 22. https://apps.who.int/iris/handle/ 10665/330991. Accessed 13 May 2020.

3. World Economic Forum. Key milestones in the spread of the coronavirus pandemic. https://www.weforum.org/agenda/ 2020/04/coronavirus-spread-covid19-pandemic-timelinemilestones/. Accessed 13 May 2020.

4. El Zowalaty M, Järhultc JD. From SARS to COVID-19: A previously unknown SARS-related coronavirus (SARSCoV-2) of pandemic potential infecting humans - Call for a One Health approach. One Health 9 (2020) 100124. https:// doi.org/10.1016/j.onehlt.2020.100124

5. Le Pan. Visualizing the History of Pandemics. https:// www.visualcapitalist.com/history-of-pandemics-deadliest/ Accessed 15 May 2020.

6. https://www.worldometers.info/coronavirus/. Accessed 19 May 2020.

7. Schneider EC. Failing the Test: The Tragic Data Gap Undermining the U.S. Pandemic Response New England Journal of Medicine May 15, 2020 DOI: 10.1056/NEJMp 2014836

8. BBC Business News. Coronavirus 'could cost global economy \$8.8tn' says ADB. https://www.bbc.com/news/ business-52671992. Accessed 17 May 2020.

9. The Indian Express. Explained: How Covid-19 has affected the global economy. https://indianexpress.com/article/ explained/explained-how-has-covid-19-affected-the-globaleconomy-6410494/. Accessed 17 May 2020.

10. White DB, Lo B. A Framework for Rationing Ventilators and 
Critical Care Beds During the COVID-19 Pandemic. JAMA 2020; 323(18): 1773-4. doi:10.1001/jama.2020.5046

11. Shurkin J. COVID-19: The Ethical Anguish of Rationing Medical Care. Discover. April 2, 2020. https://www. discovermagazine.com/health/covid-19-the-ethical-anguishof-rationing-medical-care. Accessed 14 May 2020.

12. Anon. Coronavirus: allocating ICU beds and ventilators based on age is discriminatory. The Conversation. April 22, 2020. https://theconversation.com/coronavirus-allocating-icubeds-and-ventilators-based-on-age-is-discriminatory136459. Accessed 14 May 2020.

13. Mello MM, Persad G, Douglas DB. Respecting Disability Rights - Toward Improved Crisis Standards of Care. New England Journal of Medicine May 19, 2020. DOI: 10.1056/ NEJMp2011997

14. Solomon MZ, Wynia MK, Gostin LO. Covid-19 Crisis Triage - Optimizing Health Outcomes and Disability Rights. New England Journal of Medicine May 19, 2020. DOI: 10.1056/ NEJMp2008300

15. American Medical Association. COVID-19 Ethics Guidance. https://www. ama-assn.org/topics/covid-19-ethicsguidance. Accessed 14 May 2020

16. Huxtable R. BMC Medical Ethics 2020; 21:32. https://doi.org/ 10.1186/s12910-020-00478-2

17. Dzau VJ, Kirch D, Nasca T. Preventing a Parallel PandemicA National Strategy to Protect Clinicians' Well-Being. New England Journal of Medicine 2020 May 13. doi: 10.1056/ NEJMp2011027

18. Kenny P. 90,000 healthcare workers infected with COVID19: ICN. Anadolu Agency. 6 May, 2020. https:// www.aa.com.tr/en/europe/90-000-healthcare-workersinfected-with-covid-19-icn/1831765. Accessed 13 May 2020.

19. Anon. In Memoriam: Healthcare Workers Who Have Died of COVID-19. Medscape. April 01, 2020 https:// www.medscape.com/viewarticle/927976. Accessed 13 May 2020.

20. United Nations. Policy Brief: COVID-19 and the Need for Action on Mental Health. 13 May 2020. https://www.un.org/ sites/un2.un.org/files/un_policy_brief-covid_and_ mental_health_final.pdf. Accessed 17 May 2020.

21. Liu Q, Luo D, Haase JE, et al. Lancet Glob Health 2020. April 29, 2020. https://doi.org/10.1016/S2214-109X(20)30204-7

22. Wong LE, MD, Hawkins JE, Langness S, Murrell KL, Iris P,
Sammann A. Where Are All the Patients? Addressing Covid19 Fear to Encourage Sick Patients to Seek Emergency Care. New England Journal of Medicine. Catalyst Innovations in Care Delivery. May 14, 2020. DOI: 10.1056/CAT.20.0193

23. Solomon MD, McNulty EJ, Rana JS, et al. The Covid-19 Pandemic and the Incidence of Acute Myocardial Infarction. New England Journal of Medicine May 19, 2020. DOI: 10.1056/NEJMc2015630

24. Kansagra et al. Collateral Effect of Covid-19 on Stroke Evaluation in the United States. New England Journal of Medicine May 8, 2020. DOI: 10.1056/NEJMc2014816

25. Docherty K, Butt J, de Boer R, et al. Excess deaths during the Covid-19 pandemic: An international comparison. medRxiv 2020.04.21.20073114; doi: https://doi.org/10.1101/ 2020.04.21.20073114

26. Hollander JE, Carr BG. Virtually Perfect? Telemedicine for Covid-19. New England Journal of Medicine 2020; 382:1679-1681. DOI: 10.1056/NEJMp2003539

27. Sze-Yunn P. Telehealth could be a game-changer in the fight against COVID-19. Here's why. World Economic Forum. 01 May 2020. https://www.weforum.org/agenda/2020/05/ telehealth-could-be-a-game-changer-in-the-fight-againstcovid-19-here-s-why. Accessed 17 May 2020.

28. Fretty P. Tale of COVID-19: Crisis Inspiring Innovations. Industry Week. https://www.industryweek.com/technologyand-iiot/media-gallery/21126839/tale-of-covid19-crisisinspiring-innovations. Accessed 17 May 2020.

29. Beech $P$. These new gadgets were designed to fight COVID19. World Economic Forum. 5 Apr 2020. https://www. weforum.org/agenda/2020/04/coronavirus-covid19pandemic-gadgets-innovation-technology/. Accessed 17 May 2020.

30. National Library of Medicine. PubMed.gov. https:// pubmed.ncbi.nlm.nih.gov/?term=covid+19. Accessed 14 May 2020.

31. World Health Organization. International Clinical Trial Registry Platform Search Portal. https://apps.who.int/trialsearch/ Accessed 14 May 2020.

32. Anon. Covid-19 vaccine development is picking up pace, supported by government and private funds. World Data. 12 May 2020https://www.clinicaltrialsarena.com/comment/ covid-19-vaccine-development/ Accessed 14 May 2020.

33. World Health Organization. One health. 21 September 2017. https://www.who.int/news-room/q-a-detail/one-health. Accessed 14 May 2020. 